\title{
Antibacterial and antibiofilm activity of Begonia multangula Blume. leaf extract against Candida albicans
}

\author{
1,*Hamzah, H., ${ }^{1}$ Siregar, K.A.A.K., ${ }^{2}$ Suffiana, Y., ${ }^{3}$ Yudhawan, I. and ${ }^{4}$ Nurwijayanto, A. \\ ${ }^{1}$ Faculty of Pharmacy, Universitas Muhammadiyah Kalimantan Timur, Ir. H. Juanda St. No.15, Sidodadi, \\ Samarinda Ulu Sub-District, Samarinda, Kalimantan Timur 75124 Indonesia. \\ ${ }^{2}$ Regional General Hospital Doctor Zainoel Abidin Banda Aceh 24415 Indonesia \\ ${ }^{3}$ Department of Pharmacy, Faculty of Health Sciences, Universitas Jenderal Soedirman, Purwokerto, 53123 \\ Indonesia \\ ${ }^{4}$ Balai Taman Nasional Gunung Merapi, Jl. Kaliurang KM 22,6, Hargobinangun, Pakem, Area Hutan, \\ Hargobinangun, Pakem Sub-District, Sleman District, Yogyakarta 55582 Indonesia
}

\section{Article history:}

Received: 27 July 2021

Received in revised form: 30

August 2021

Accepted: 16 December 2021

Available Online: 20

February 2022

\section{Keywords:}

Begonia multangula Blume leaf,

Antifungal,

Biofilm,

Candida albicans,

Infection

DOI:

https://doi.org/10.26656/fr.2017.6(1).560

\begin{abstract}
Candida albicans is a fungus that is included in the normal microbiota of humans. In general, C. albicans remains a lifelong commensal microorganism. This fungus has a hazardous impact. C. albicans can cause infection and is fatal. The spread of this fungus is one of the factors caused by antibiotic resistance, which causes $C$. albicans to be resistant and form strong colonies (biofilms) to survive. Natural ingredients for treatment is an alternative that is often used by the community because their use is effortless and practical. One of the plants is the leaves of Begonia multangula Blume. This plant is known to have potent antifungal activity, but its antibiofilm activity against $C$. albicans has not yet been reported in-depth about its antibiofilm. The discovery of new antibiofilm against $C$. albicans biofilms is a way to prevent the effects of infections caused by these biofilms. This research is a form of dedication to the effectiveness of Begonia multangula Blume leaf extract in inhibiting and eradicating C. albicans biofilm formation. Planktonic testing, inhibition, and biofilm eradication activity were carried out using the microtiter broth method. Antibiofilm activity of begonia leaves on C. albicans was measured by calculating the minimum concentration of biofilm inhibitor $\left(\mathrm{MBIC}_{50}\right)$. Data were analyzed using the Statistical Package for the Social Sciences (SPSS) with a 95\% confidence level. The begonia leaves showed inhibitory activity against the tested $C$. albicans biofilm formation. Begonia multangula Blume leaf extract $1 \%$ gave C. albicans antibacterial activity of $75 \pm 0.01 \%$ and mid-phase antibiofilm activity of $65.21 \pm 0.01 \%$ and maturation phase of $50.11 \pm 0.01$. The results also provided evidence that the ethanolic extract of $C$. albicans can degrade (eradication) the formation of $C$. albicans biofilms. Therefore, the ethanol extract of begonia leaves can be developed as a new antibiofilm agent against $C$. albicans.
\end{abstract}

\section{Introduction}

Candida albicans is a fungus that is included in the normal microbiota of humans. Candida species are the $2^{\text {nd }}$ most common parasitic disease-causing specialist worldwide and occupy the $5^{\text {th }}$ position among hospitalacquired pathogens (Aires et al., 2020). In general, $C$. albicans remains a lifelong commensal microorganism. However, this fungus has a hazardous impact, $C$. albicans can cause infections, both mild around the skin surface to systemic ones that can cause death (Mutiawati, 2016). One of the causative factors that aggravate the

*Corresponding author.

Email:hh241@umkt.ac.id situation is where the fungus grows stronger, which causes the formation of biofilms (Mayer et al., 2013). Biofilms are heterogeneous communities of microorganisms attached to abiotic or biotic surfaces, encased in a matrix of extracellular polymeric substances (EPS), and forming complex structures (Cowan et al., 2000; Anderson et al., 2003; Hall-Stoodley et al., 2004; Cavalheiro et al., 2018). Biofilms can be formed by one type of microorganism in the form of a mixture of various species of bacteria, fungi, algae, and yeasts, together with foreign substances (Costerton et al., 1995; Harriott et al., 2010). Biofilms often pose a problem in eISSN: 2550-2166 / C 2022 The Authors. Published by Rynnye Lyan Resources 
the treatment of infections. Biofilms are a significant barrier to treatment because their cells can show up to a 1000-fold increase in antibiotic resistance compared to planktonic cells (Hoyle et al., 1991; Pratiwi et al., 2015). Microbial biofilm can function as a protector to ensure the microbes have resistance to common antimicrobials and avoid the host cell immune system.

This leads to the low effectiveness of antimicrobials due to the prevalence of antimicrobials against microbial resistance (Ceri et al., 1999; Donlan, 2002). Due to the low effectiveness of antimicrobial agents against them, infections associated with biofilm-producing microbes can harm humans. Biofilms develop along with increasing clinical infection in host cells, these biofilms are one of the virulence and resistance factors (Hertiani et al., 2011; Hamzah et al., 2018). Candida albicans is a highly pathogenic biofilm-forming fungus. In immunocompromised individuals, C. albicans emerges as an opportunistic pathogen by colonizing epithelial tissue and causing superficial infection. Of the 345 cases of candidemia studied in a hospital in Spain, the mortality reached $44 \%$, with details of this figure, $51 \%$ was caused by $C$. albicans infection. Bacteria in the form of biofilms differ from planktonic bacteria in various ways of growth. One of the consequences is that the bacteria in the biofilm are shown to be more resistant to antibiotics and antimicrobials (Rodríguez-Cerdeira et al., 2019). Today's use of natural ingredients is one way to carry out herbal treatment as they are easily obtained and easy to process into herbal medicines. One of the plants that have antifungal activity is the genus begonia. This plant grows and develops in Indonesia. Currently, there is still data that reveals its potential and its use for the wider community. Begonias are commonly found as ornamental plants, herbaceous plants with extensive distribution from the tropics to subtropics, and have many fans and begonia associations (Donlan, 2002; Ramesh et al., 2002).

Begonia multangula is one of the species that is widespread on the islands of Sumatra, Java, Bali, to the Lesser Sunda Islands, begonias have slightly woody characteristics at the base, red or dark green hairs, and round egg-shaped leaves (Kiew, 2005; Efendi et al., 2018). Since the $17^{\text {th }}$ century, many types of Begonias have been found in many countries such as Mexico, Central America, South America, Asia, and Africa (Efendi et al., 2018). It was also found that some of the benefits of this plant were found, supported by previous research showing that Begonia $\mathrm{sp}$. has antibacterial activity against Staphylococcus aureus and Escherichia coli (Wiriadinata et al., 2002; Undaharta et al., 2011; Efendi et al., 2018). In addition, this plant is also reported to contain phenolic compounds, flavonoids, steroids, terpenoids, and alkaloids that play a role in antibacterial and antifungal activity (Andrews, 2001; Siregar et al., 2018). Meanwhile, other previous studies also explained that biofilms could be controlled by utilizing chemical compounds obtained from natural materials (Nuryastuti et al., 2018; Karpova et al., 2019). In general, there is not much information and research on the health benefits of begonias. In addition, to date, there have been no studies reporting the activity of Begonia multangula Blume against $C$. albicans biofilms. Therefore this study is to examine the health benefits of the genus begonia. This study aimed to determine the antibiofilm activity of Begonia multangula Blume against the biofilm of the microorganism $C$. albicans including a brief literature review and previous relevant work with references.

\section{Materials and methods}

\subsection{Equipment}

The equipment used in this study were Laminar Air Flow, incubator (IF-2B) (Sakura, Japan), micropipette (Gilson, France), multichannel micropipette (Socorex, Switzerland), microplate flat-bottom polystyrene 96 well (Iwaki, Japan), microtiter plate reader (Optic Ivymen System 2100-C, Spain), spectrophotometry (Genesys 10 UV Scanning, 335903) (Thermo Scientific Spectronic, USA), autoclave (Sakura, Japan), analytical balance (AB204 -5, Switzerland).

\subsection{Materials}

The materials used in this study were leaf extract of Begonia multangula Blume with ethanol extract solvent, isolate of $C$. albicans biofilm-forming standard $(C$. albicans ATCC 10231) from the collection of the Microbiology Laboratory of the Faculty of Pharmacy UGM, Nystatin, DMSO 1\%, NaCl, McFarland Standard 0.5 sterile distilled water, Sabouraud Dextrose Broth (SDB) media, RPMI media, PBS (Phosphate Buffer Saline) solution, $1 \%$ crystal violet, disposable gloves, and masks.

\subsection{Fungal strains}

Candida albicans was grown for $72 \mathrm{hrs}$ at $37^{\circ} \mathrm{C}$ in Sabouraud Dextrose Broth (SDB). Optical density 600 of microbial culture adjusted to 0.1 equivalent to McFarland standard $0.5-1.5 \times 10^{8} \mathrm{CFU} / \mathrm{mL}$ )

\subsection{Antifungal testing}

The antifungal test was carried out using the microdilution method. Tests were carried out on microtiter plate flat-bottom polystyrene 96 wells with a series of Begonia multangula Blume leaf extract levels, namely $1 \%, 0.5 \%, 0.25 \%$, and $0.125 \% \mathrm{w} / \mathrm{v}$. The control 
used was a positive control using nystatin $1 \% \mathrm{w} / \mathrm{v}$. The negative control was in the form of a microbial suspension, and the solvent control was adjusted to the solvent of the test compound. Into each well, RPMI media was inserted into the microplate then incubated at $37^{\circ} \mathrm{C}$ for $72 \mathrm{hrs}$. Microplate absorbance reading process using a microplate reader at a wavelength of $595 \mathrm{~nm}$.

\subsection{Test of inhibition of biofilm formation mid-phase (24 hours) and maturation phase (48 hours) using the microbroth dilution method}

To assess the effect of the test isolates on the formation of mono-species C. albicans biofilm, a 96well flat-bottom polystyrene microtiter plate was used (Pierce et al., 2010). A total of $100 \mu \mathrm{L}$ of C. albicans suspension $\left(10^{7} \mathrm{CFU} / \mathrm{mL}\right)$ was added to each wells microtiter plate and then incubated at $\pm 37^{\circ} \mathrm{C}$ for 90 minutes for the biofilm attachment phase. After the incubation period, the plates were washed with $150 \mu \mathrm{L}$ of sterile distilled water three times to remove nonadherent cells. A total of $100 \mathrm{~L}$ of media containing Begonia multangula Blume leaf extract with a series concentration $(1 \%, 0.5 \%, 0.25 \%, 0.125 \% \mathrm{w} / \mathrm{v})$ was added to each well that had been washed. A medium without microbial growth was used as a control medium, and a microbial suspension was used as a negative control. The microbial suspension was used as a positive control, which was given antifungal nystatin at $1 \% \mathrm{w} / \mathrm{v}$. The plates were then incubated at $37^{\circ} \mathrm{C}$ for $24 \mathrm{hrs}$ to form the mid-phase biofilm and $48 \mathrm{hrs}$ for the formation of the maturation phase biofilm.

Then the plate was washed using distilled water three times and dried at room temperature for 5 mins to remove the remaining water. A total of $125 \mu \mathrm{L}$ of $1 \%$ crystal violet solution was added to each well to colour the formed biofilm, both dead cells and live cells, which are also components of the biofilm, then incubated at room temperature. After incubation at room temperature, the microplate was washed with running water three times to remove the remaining crystal violet, and $200 \mu \mathrm{L}$ of $96 \%$ ethanol was added to each well to dissolve the formed biofilm. Optical Density (OD) readings were carried out with a microplate reader at a wavelength of $595 \mathrm{~nm}$.

The OD value is then used to calculate the per cent inhibition in the following equation:

$$
\% \text { Inhibition }=\frac{\left(\mathrm{OD}_{\text {negative control mean }}-\mathrm{OD}_{\text {test sample mean }}\right)}{\text { OD negative control mean }} \times 100
$$

The sample level that can inhibit at least $50 \%$ of biofilm formation is considered Minimal Biofilm Inhibition Concentration $\mathrm{MBIC}_{50}$ (Maramis et al., 2017; Efendi et al., 2018).

\subsection{Biofilm eradication activity testing}

The eradication activity of the leaf extract of Begonia multangula Blume was also examined on the biofilm strain of $C$. albicans ATCC 10231 using the previously described method. Biofilms were inoculated in microtiter plates like that described above. After incubation at $37^{\circ} \mathrm{C}$ for $48 \mathrm{hrs}$, the plates were washed with $150 \mu \mathrm{L}$ of sterile distilled water three times to remove nonadherent cells. A total of $100 \mu \mathrm{L}$ of media containing Begonia multangula Blume leaf extract with a concentration series $(1 \% \mathrm{w} / \mathrm{v}, 0.5 \% \mathrm{w} / \mathrm{v}, 0.25 \% \mathrm{w} / \mathrm{v}$, and $0.125 \% \mathrm{w} / \mathrm{v}$ ) was added to each well that had been prepared. Washed and then incubated again at $37^{\circ} \mathrm{C}$ for $48 \mathrm{hrs}$. Nystatin at a concentration of $1 \% \mathrm{w} / \mathrm{v}$ was used as a positive control. After incubation, the plates were washed three times with $200 \mathrm{~mL}$ of sterile PBS to remove adhering cells. Biofilm degradation was quantified with $125 \mu \mathrm{L} 1 \%$ crystal violet solution into each well, then incubated at room temperature for 15 mins. After incubation, the microplate was washed with PBS, and $200 \mu \mathrm{L}$ of $96 \%$ ethanol was added to each well to dissolve the formed biofilm. Optical Density (OD) readings were carried out with a microplate reader at a wavelength of $595 \mathrm{~nm}$ (Ali et al., 2010).

\subsection{Scanning Electron Microscopy testing}

Cells were grown directly on coverslips and incubated at $37^{\circ} \mathrm{C}$ for $24 \mathrm{hrs}$ for the intermediate phase. The test compound is a compound known to give $\mathrm{MBIC}_{50} / \mathrm{MBEC}_{50}$ activity at a concentration of $0.5 \% \mathrm{w} / \mathrm{v}$ (Hamzah et al., 2020). After the mid-phase biofilm was formed, the coverslip was carefully washed with $1 \%$ PBS twice, followed by washing with $2 \%$ paraformaldehyde, $2 \%$ glutaraldehyde, $0.15 \mathrm{M}$ sodium cacodylate, and the sample was prepared for observation under SEM. The sputter specimen was coated with a gold layer, and the sample was observed under the JEOL JSM-6400 Scanning electron microscopy (SEM). The image is processed using Photoshop software.

\subsection{Statistical methods}

Statistical significance of the data was determined using ANOVA, followed by a normality test using the Shapiro - Wilk test. Differences were considered significant with $p$ values of 0.05 or less. The data were analyzed using the Statistical Package for the Social Sciences (SPSS) with a 95\% confidence level.

\section{Results and discussion}

The biofilm formation process consists of 5 stages, namely the first attachment of bacteria to the surface of particular objects due to van der Walls forces. Second, bacterial cells have been permanently attached to the 
object's surface due to the formation of exopolymer material. Third, biofilms and microcolonies begin to form. Fourth, the presence of biofilms increases and forms a three-dimensional structure that protects cells. Fifth, there is the dispersion of cells (separation) from the parent biofilm to then stick to the surface of the new object, and the process of biofilm formation occurs in other places (Al-Fattani et al., 2006; Pratiwi et al., 2017).

3.1 Effect of Begonia multangula extract on C. albicans planktonic cell biofilm formation

The results showed (Figure 1) that the begonia extract had the activity of inhibiting the growth of $C$. albicans planktonic cells. Begonia extract with a concentration of $1 \% \mathrm{w} / \mathrm{v}$ gave the most significant inhibitory result, which was $75 \%$, compared to the $1 \%$ $\mathrm{w} / \mathrm{v}$ nystatin control group (70\%).

In the biofilm formation phase, it can prevent the development of the fungus $C$. albicans. The biofilm structure in this phase is not yet fully formed, and the Extracellular Polymeric Substances (EPS) matrix formed is still tiny and thin, this test sample is antimicrobial and can damage microbial defences (Prakash et al., 2003).

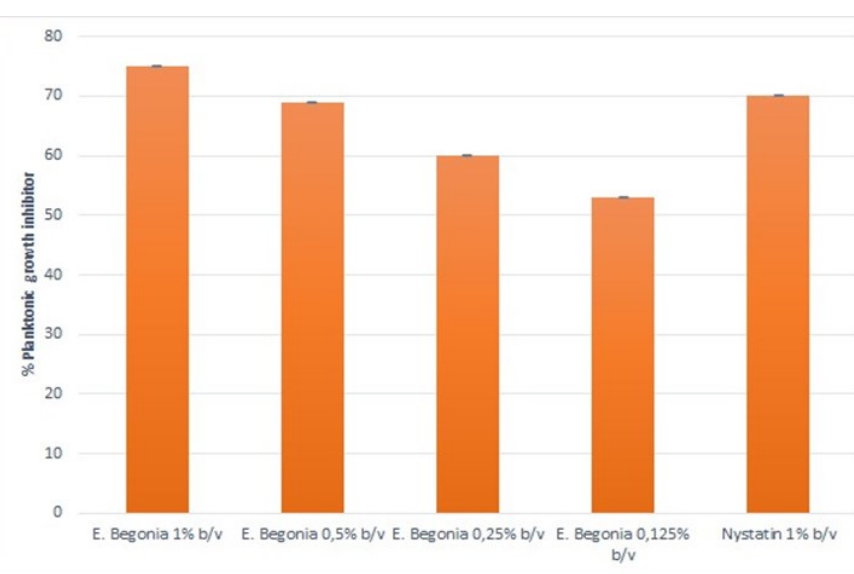

Figure 1. Inhibitory activity of planktonic with various concentrations, ANOVA with $\mathrm{p}<0.05$

\subsection{Effect of Begonia multangula extract on biofilm} formation Mid-phase (24 hours) and $\mathrm{MBIC}_{50}$ maturation phase (48 hours)

This study showed that the inhibitory power of begonia leaves against $C$. albicans was $70.00 \pm 0.01$ and had almost the same activity as nystatin as a controlled drug $(60 \pm 0.01)$. The 50 activity of begonia leaf extract was about $0.25 \% \mathrm{v} / \mathrm{v}\left({ }^{*} \mathrm{P}<0.05\right)$ (Table 1$)$. In the middle phase, it is easier than microbes that form biofilms in the maturation phase. Likewise, in the maturation phase, bacteria form a biofilm with a very thick matrix, accordingly, the antimicrobial is rather difficult to penetrate the target cell defences because the microbes are wrapped and protected by the EPS matrix (Pratiwi et al., 2020). The process of a compound inhibiting the growth of the biofilm phase is by inhibiting the attachment of microbes to the surface so that the development of the biofilm is disrupted. If the biofilm development is disturbed, it will affect the biofilm structure to increase its defence against antimicrobials.

Table 1. $\mathrm{IC}_{50}$ and $\mathrm{EC}_{50}$ values of begonia leaf extract against mono species $C$. albicans at all biofilm growth phases (ANOVA with $\mathrm{p}<0.05$ )

\begin{tabular}{cccc}
\hline Compound & $\begin{array}{c}\mathrm{MBIC}_{50 \% \mathrm{v} / \mathrm{v}} \\
\text { Mid phase (24 } \\
\text { hrs) }\end{array}$ & $\begin{array}{c}\mathrm{MBIC}_{50 \% \mathrm{v} / \mathrm{v}} \\
\text { Maturation } \\
\text { Phase (48 hrs) }\end{array}$ & $\begin{array}{c}\mathrm{MBEC}_{50 \% \mathrm{v} / \mathrm{v}} \\
\text { Eradication } \\
\text { Phase }\end{array}$ \\
\hline $\begin{array}{c}\text { Begonia Leaf } \\
\text { Extract }\end{array}$ & $0.25 \% *$ & $0.5 \% *$ & $1 \% *$ \\
\hline
\end{tabular}

*significant correlation $(\mathrm{P}$ value $<0.05)$. $\mathrm{MBIC}_{50}$ value is a concentration of test compounds that can inhibit the growth of $50 \%$. Determined by comparing the optical density between the treatment group with the control group without drugs by first calculating the cut-off point with the formula: (OD control - OD blank) $\times 50 / 100$

The activity in the maturation phase decreased to $(55.00 \pm 0.01)$ while the nystatin control was $49.00 \pm 0.01$. (Figure 2) with the $\mathrm{MBIC}_{50}$ activity value of begonia leaf extract around $0.5 \% \mathrm{v} / \mathrm{v}\left({ }^{*} \mathrm{P}<0.05\right)$ (Table 1$)$. In this study, it was reported that there was a decrease in biofilm inhibitory activity by Begonia multangala extract from the middle phase ( $24 \mathrm{hrs}$ ) to the maturation phase (48 hrs), this is because the growth time in the maturation phase takes a long time compared to the middle phase, to ensure that in the maturation phase more concentration needed. The higher dose of Begonia multangala extract inhibited biofilm growth compared to the intermediate phase. This was due to the synergism between bacteria with each other as well as communication between cells in the biofilm structure (Hamzah et al., 2020). In this phase, C. albicans has produced an EPS matrix. This can be seen from the bottom of the wells and the periphery of wells 96 , which is indicated by mucus adhering to the wells. In addition, the presence of biofilm can also be seen from the process of giving crystal violet. In this phase, the ethanol extract will be more difficult to penetrate the defences of $C$. albicans because it has already formed a biofilm, where the biofilm structure is more complex and organized with each other. This causes a decrease in activity in the 24-hr phase of biofilm inhibition (Hamzah et al., 2021). In the previous statement, the antimicrobial agents would be more difficult to penetrate the biofilm defences (Ramage et al., 2012; Hamzah et al., 2019). C. albicans, a major regulator of biofilm development, is also involved in filamentous growth, given the typical hyphal differentiation during this process. That is the case for Efg1 and Cph1, which positively control the expression of genes required for hyphal growth, such as ECE1, HYR1, HWP1, and ALS3 (Bailey et al., 1996; Harriott et al., 2010). 


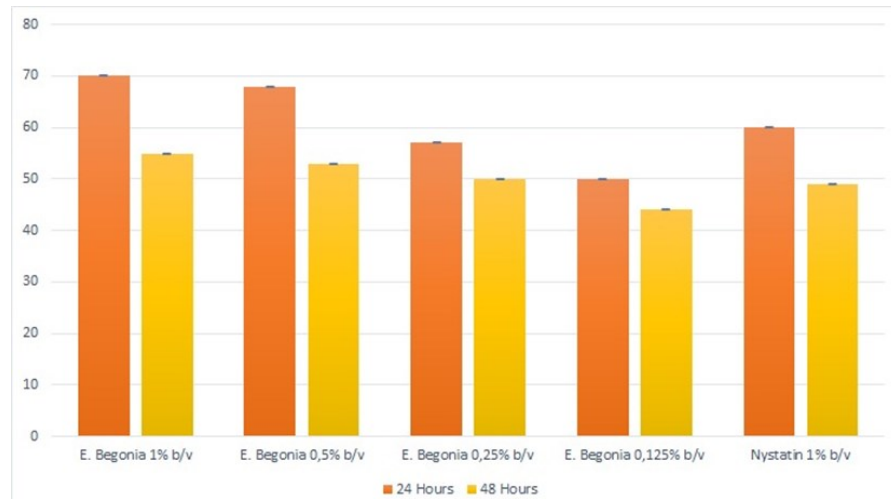

Figure 2. Inhibition of biofilms in the middle phase (24 hours) and maturation phase (48 hours).

\subsection{Effect of Begonia multangula extract on eradication phase biofilm formation}

The eradication phase is long in biofilm formation. The biofilm that is formed is also more robust and works synergistically with each other. The degradation phase has a more robust biofilm defence than the maturation phase. In this phase, as the composition of the EPS matrix is very thick, it becomes extremely difficult for antibiofilm agents to penetrate it because it takes an adequate amount of biofilms has grown to provide the bacteria with their nutritional needs. Microbes that form biofilms in the degradation phase are more difficult to destroy than those in the intermediate and inhibitory phases. This is because the biofilm has grown long enough that a complex biofilm defence has been formed, embedded more deeply, and more EPS is produced that the efficacy of the antibiotic to penetrate it decreases. In addition, microbes have also established quorum sensing communication to enable further protection against antibiotic (Hamzah et al., 2018).

The eradication phase biofilm defence is stronger than the maturation phase. As the EPS composition perfects itself due to a longer period of biofilm growth, the more nutrients it obtains (Hamzah et al., 2021; Hamzah et al., 2022). The results showed that Begonia multangula extract had inhibitory activity in the eradication phase of biofilm formation where begonia leaves with a concentration of $1 \% \mathrm{w} / \mathrm{v}$ had activity in the degradation phase of $55.00 \pm 0.01$, while nystatin was $49.00 \pm 0.01$ where the $\mathrm{MBIC}_{50}$ activity value of begonia leaf extract was around $1 \% \mathrm{v} / \mathrm{v}\left({ }^{*} \mathrm{P}<0.05\right)$ (Table 1$)$.

The results in Figure 3 showed that 1\% w/v begonia extract can damage the defences in the formation of $C$. albicans biofilms. This compound can break the formation pathway between cells to reduce the number of biofilms formed. Positive control Nystatin 1\% w/v had lower $C$. albicans biofilm eradication activity than begonia extract with the same concentration. Microbes that have formed biofilms at the maturation and eradication stages are becoming increasingly difficult to eradicate. This is because the formation of the EPS matrix and its physiology is complete and has sufficient thickness to protect microorganism cells from the external environment. In addition, it has been formed between microorganisms in the biofilm by quorum sensing.

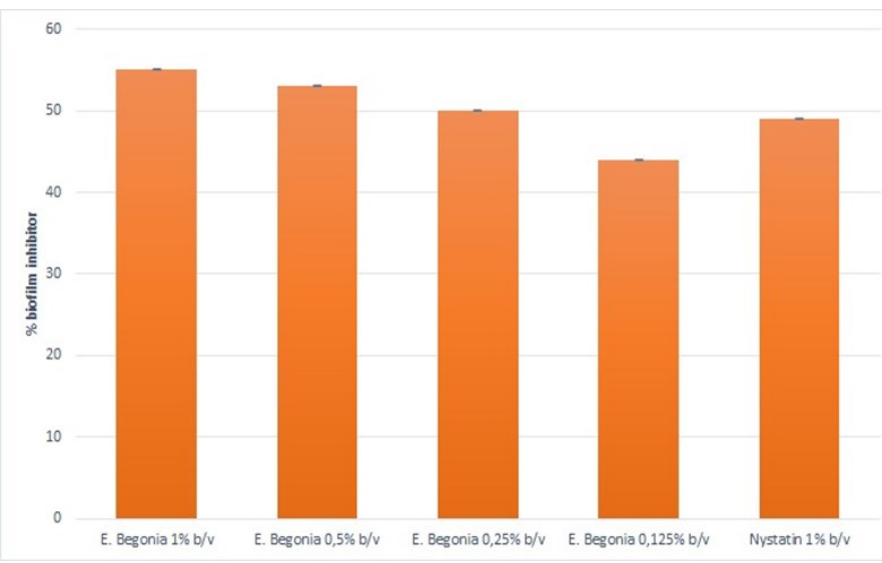

Figure 3. Biofilm eradication activity of Begonia Leaf extract

The process of a compound inhibits the growth of the biofilm phase by inhibiting the attachment of microbes to the surface and interferes with the development of the biofilm (Ali et al., 2010). If the biofilm development is disturbed, this will affect the biofilm structure, therefore, decreasing its defence against antimicrobials. Bacteria in the form of biofilms differ from planktonic bacteria in various ways of growth. One consequence is that the bacteria in the biofilm are shown to be more resistant to antibiotics and antimicrobials (Hess et al., 2012). Increased Candida infection in the biofilm causes and contributes to high antifungal resistance and escape from host defences, resulting in persistent infection (Olszewska et al., 2020). The decrease in activity in the degradation phase was due to biofilm formation in this phase being longer than the intermediate phase. This caused the formation of $C$. albicans biofilms to be more complex and structured, enabling more EPS matrix produced to protect $C$. albicans microbes (Hamzah et al., 2021).

These results are by the conditions during the biofilm development process. The middle phase is where the biofilm begins to form and begins to protect the planktonic cells from the outside environment. Furthermore, in the maturation phase, the biofilm formed was good, and the EPS matrix became thicker difficult to penetrate by interfering with the compounds used. Therefore, this phase is good enough to protect planktonic cells from the outside environment. The ability to form biofilms is one of the virulence factors of C. albicans that can lead to increased tolerance to antibiotics and disinfectants as well as resistance to phagocytosis and other immunocompetent cells (Høiby 
et al., 2010).

These findings indicate that begonia leaves have the potential to be developed as antibiofilm agents. Further research can be carried out to determine the composition of begonia leaf components and the mechanism of action or their components as antibiofilm, especially saponins. Saponins are polar surfactants that will reduce the surface tension of the sterol membrane of the cell wall of C. albicans, thus causing membrane permeability disturbances which results in the entry of materials or substances needed can be disrupted. Eventually, the cells swell and burst. It is affirmed that antibiotics can affect bacteria through bactericidal, such as inducing morphological changes (Hamzah et al., 2022).

\subsection{Results of Scanning Electron Microscopy} polymicrobial biofilm of the fungus Candida albicans before administration of begonia leaf extract

The fungus has already formed a highly structured and complex biofilm (Figure 4a). This causes the compound to have difficulty providing maximum inhibition due to the thickness of the EPS matrix that protects the C. albicans biofilm. The biofilm structure is very complex, consisting of 3 layers, the innermost or connective layer that adheres to the surface of the tissue material, the bottom layer in which there are adhering microorganisms and an outer layer called the surface layer. It can be used as an entry point for planktonic organisms (Beiko et al., 2004). More than 90\% of clinical isolates produce $C$. albicans with a polysaccharide capsule or thin membrane that plays a role in bacterial virulence (Chaerunisa, 2015).

Administration of begonia leaf extract $0.5 \% \mathrm{w} / \mathrm{v}$ (Figure $4 \mathrm{~b}$ ) to the fungal biofilm resulted in a decrease in the number of cells indicated by the cells becoming broken and hollow produce biofilms do not become scattered. This is because the administration of begonia leaf extract tested destroys the bacteria. After all, its active compounds can attack the EPS matrix of C. albicans. The secondary compounds possessed by begonia leaves can provide support in its working mechanism, namely, saponins can diffuse through the outer membrane and cell walls of susceptible bacteria and then bind to the cytoplasmic membrane as it disrupts and reduces cell stability. This causes the cytoplasm to leak out of the cell resulting in bacterial cell death (Taufik et al., 2015). Saponin compounds are responsible for this activity. Where its activity is faster than the growth of biofilm, which causes the biofilm the be unable to form a complex structure that can produce more matrix Extracellular Polymeric Substances (EPS), which would consequently provide a strong defense against $C$. albicans, because the compounds in the drug cannot penetrate target cells (Coleman et al., 2010).

\section{Conclusion}

This study concluded that Begonia multagula Blume leaf extract could inhibit the growth of $C$. albicans biofilm. Begonia multagula Blume leaf extract can be developed as a candidate for a new antibiofilm agent against the fungal biofilm of $C$. albicans. This is evidenced in the results of research where some graphic results show above $40 \%$, which means this extract can be developed into an antibiofilm agent.

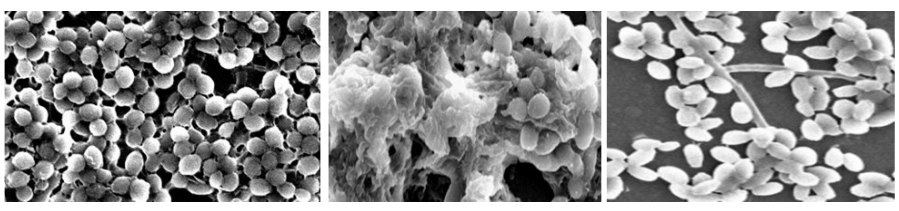

(a)

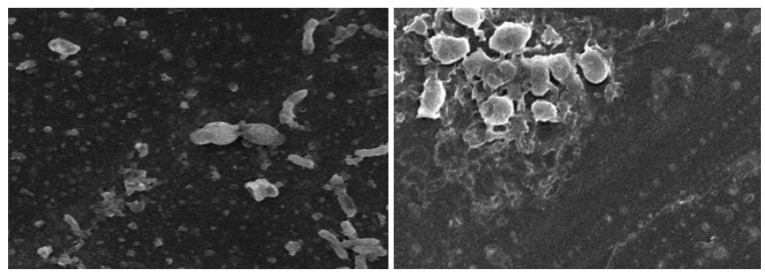

(b)

Figure 4. Scanning Electron Microscopy (SEM) images of the fungus $C$. albicans treated before administration of the test compound, (a); after administration of begonia leaf extract (b)

\section{Conflict of interest}

The authors declare no conflict of interest.

\section{Acknowledgments}

The author would like to thank the Microbiology Laboratory of the Faculty of Pharmacy, Gadjah Mada University.

\section{References}

Aires, A., Barreto, A.S. and Semedo-Lemsaddek, T. (2020). Antimicrobial Effects of Essential Oils on Oral Microbiota Biofilms: The Toothbrush In Vitro Model. Antibiotics, 10(1), 21. https:// doi.org/10.3390/antibiotics10010021

Al-Fattani, M.A. and Douglas, L.J. (2006). Biofilm matrix of Candida albicans and Candida tropicalis: chemical composition and role in drug resistance. Journal of Medical Microbiology, 55(8), 999-1008. https://doi.org/10.1099/jmm.0.46569-0

Ali, I., Khan, F G., Suri, K.A., Gupta, B.D., Satti, N.K., Dutt, P., Afrin, F., Qazi, G.N. and Khan, I.A. (2010). In vitro antifungal activity of hydroxychavicol isolated from Piper betle L. Annals of Clinical Microbiology and Antimicrobials, 9(1), 7. https:// 
doi.org/10.1186/1476-0711-9-7

Anderson, G.G., Palermo, J.J., Schilling, J.D., Roth, R., Heuser, J. and Hultgren, S.J. (2003). Intracellular Bacterial Biofilm-Like Pods in Urinary Tract Infections. Science, 301(5629), 105-107. https:// doi.org/10.1126/science. 1084550

Andrews, J.M. (2001). Determination of minimum inhibitory concentrations. Journal of Antimicrobial Chemotherapy, 48(Suppl. 1), 5-16. https:// doi.org/10.1093/jac/48.suppl_1.5

Bailey, D.A., Feldmann, P.J., Bovey, M., Gow, N.A. and Brown, A.J. (1996). The Candida albicans HYR1 gene, which is activated in response to hyphal development, belongs to a gene family encoding yeast cell wall proteins. Journal of Bacteriology, 178 (18), 5353-5360. https://doi.org/10.1128/ jb.178.18.5353-5360.1996

Beiko, D.T., Knudsen, B.E., Watterson, J.D., Cadieux, P.A., Reid, G. and Denstedt, J.D. (2004). Urinary Tract Biomaterials. Journal of Urology, 171(6 Part 1), 2438-2444. https:// doi.org/10.1097/01.ju.0000125001.56045.6c

Cavalheiro, M. and Teixeira, M.C. (2018). Candida Biofilms: Threats, challenges, and promising strategies. Frontiers in Medicine, 5, 28. https:// doi.org/10.3389/FMED.2018.00028

Ceri, H., Olson, M.E., Stremick, C., Read, R.R., Morck, D. and Buret, A. (1999). The Calgary Biofilm Device: New Technology for Rapid Determination of Antibiotic Susceptibilities of Bacterial Biofilms. Journal Of Clinical Microbiology, 37(6), 17711776. $\quad$ https://doi.org/10.1128/JCM.37.6.17711776.1999

Chaerunisa, R. (2015). Pengujian Aktivitas Penghancuran biofilm Staphylococcus aureus oleh seduhan daun teh putih (Camellia sinensis (L.) Kuntze). Indonesia: Universitas Islam Negeri Syarif. [In Bahasa Indonesia].

Coleman, J.J., Okoli, I., Tegos, G.P., Holson, E.B., Wagner, F.F., Hamblin, M.R. and Mylonakis, E. (2010). Characterization of Plant-Derived Saponin Natural Products against Candida albicans. ACS Chemical Biology, 5(3), 321-332. https:// doi.org/10.1021/cb900243b

Costerton, J.W., Lewandowski, Z., Caldwell, E.D., Korber, D.R. and Lappin-Scott, H.M. (1995). Microbial Biofilms. Annual Review of Microbiology, 49(1), 711-745. https://doi.org/10.1146/ annurev.mi.49.100195.003431

Cowan, S.E., Gilbert, E., Liepmann, D. and Keasling, J.D. (2000). Commensal Interactions in a DualSpecies Biofilm Exposed to Mixed Organic
Compounds. Applied and Environmental Microbiology, 66(10), 4481-4485. https:// journals.asm.org/journal/aem

Donlan, R.M. (2002). Biofilms: Microbial Life on Surfaces. Emerging Infectious Diseases, 8(9), 881890. https://doi.org/10.3201/eid0809.020063

Efendi, M., Azizah, N., Supriyatna, A. and Destri, D. (2018). Keragaman Jenis Dan Preferensi Ekologi Begonia Liar Di Kawasan Remnant Forest Kebun Raya Cibodas. Jurnal Ilmu-Ilmu Hayati, 16(3). https://doi.org/10.14203/beritabiologi.v16i3.2873 [In Bahasa Indonesia].

Hall-Stoodley, L., Costerton, J.W. and Stoodley, P. (2004). Bacterial biofilms: from the Natural environment to infectious diseases. Nature Reviews Microbiology, 2(2), 95-108. https://doi.org/10.1038/ nrmicro821

Hamzah, H., Hertiani, T., Pratiwi, S.U.T. and Nuryastuti, T. (2021). Efek Saponin Terhadap Penghambatan Planktonik Dan Mono-Spesies Biofilm Candida albicans ATCC 10231 Pada Fase Pertengahan, Pematangan dan Degaradasi. Majalah Farmaseutika, 17, 198-205. https://doi.org/10.22146/ farmaseutik.v17i2.54444 [In Bahasa Indonesia].

Hamzah, H., Hertiani, T., Pratiwi, S.U.T., Nuryastuti, T. and Gani, A.P. (2020). Antibiofilm studies of zerumbone against polymicrobial biofilms of Staphylococcus aureus, Escherichia coli, Pseudomonas aeruginosa, and Candida albicans. International Journal of Pharmaceutical Research, 12(Suppl. 1), 1307-1314. https://doi.org/10.31838/ ijpr/2020.SP1.211

Hamzah, H., Hertiani, T., Utami Tunjung Pratiwi, S., and Nuryastuti, T. (2019). The Inhibition Activity of Tannin on the Formation of Mono-Species and Polymicrobial Biofilm Escherichia coli, Staphylococcus aureus, Pseudomonas aeruginosa, and Candida albicans. Majalah Obat Tradisional, 24 (2), 110-118. https://doi.org/10.22146/mot.44532

Hamzah, H., Pratiwi, S.U.T. and Hertiani, T. (2018). Efficacy of thymol and eugenol against polymicrobial biofilm. Indonesian Journal of Pharmacy, 29(4), 214-221. https://doi.org/10.14499/ indonesianjpharm29iss4pp221

Hamzah, H., Yudhawan, I., Rasdianah, N., Setyowati, E., Nandini, E. and Utami, S. (2022). Clove Oil Has the Activity to Inhibit Middle, Maturation and Degradation Phase of Candida tropicalis Biofilm Formation. Biointerface Research in Applied Chemistry, 12(2), 1507-1519. https:// doi.org/10.33263/BRIAC122.15071519

Harriott, M.M. and Noverr, M.C. (2010). Ability of 
Candida albicans Mutants To Induce Staphylococcus aureus Vancomycin Resistance during Polymicrobial Biofilm Formation. Antimicrobial Agents And Chemotherapy, 54(9), 3746-3755. https://doi.org/10.1128/AAC.00573-10

Hertiani, T., Pratiwi, S.U.T.P., Irianto, I.D.K., Adityaningrum and Pranoto, B. (2011). Effect of Indonesian medicinal plants essential oils on Streptococcus mutans biofilm. Majalah Farmasi Indonesia, 22(3), 174-181.

Hess, D.J. Henry-Stanley, M.J., Barnes, A.M.T., Dunny, G.M. and Wells, C.L. (2012). Ultrastructure of a Novel Bacterial Form Located in Staphylococcus aureus In Vitro and In Vivo Catheter-Associated Biofilms. Journal of Histochemistry and Cytochemistry, 60(10), 770-776. https:// doi.org/10.1369/0022155412457573

Høiby, N., Bjarnsholt, T., Givskov, M., Molin, S. and Ciofu, O. (2010). Antibiotic resistance of bacterial biofilms. International Journal of Antimicrobial Agents, 35(4), 322-332. https://doi.org/10.1016/ j.ijantimicag.2009.12.011

Hoyle, B.D. and Costerton, J.W. (1991). Bacterial resistance to antibiotics: The role of biofilms. In Jucker, E. (Ed.) Progress in Drug Research/ Fortschritte der Arzneimittelforschung/Progrès des recherches pharmaceutiques, p. 91-105. Switzerland: Birkhäuser Basel. https://doi.org/10.1007/978-30348-7139-6_2

Karpova, E.A., Nabieva, A.Y., Fershalova, T.D., Yakimova, Y.L. and Tsybulya, N.V. (2019). Flavonoids and antimicrobial properties of Begonia fischeri var. Palustris in vitro plantlets. Online Journal of Biological Sciences, 19(1), 20-27. https:// doi.org/10.3844/ojbsci.2019.20.27

Kiew, R. (2005). Begonias of Peninsular Malaysia. Singapore: National History Publication and Singapore Botanic Gardens National Parks Broad.

Maramis, R.N., Kalonio, D.E. and Rindengan, E.R. (2017). Utilization of Gedi Merah Leaf (Abelmoschus manihot L. Medik) Mucilage Native from North Sulawesi as Emulsifier in Emulsion Preparations. Jurnal Tumbuhan Obat Indonesia, 10 (1), $\quad 17 \quad-24 \quad \mathrm{https} / / /$ doi.org/10.22435/ toi.v10i1.7125.17-24 [In Bahasa Indonesia].

Mayer, F.L., Wilson, D. and Hube, B. (2013). Candida albicans pathogenicity mechanisms. Virulence, 4(2), 119-128. https://doi.org/10.4161/viru.22913

Mutiawati, V.K. (2016). Pemeriksaan Mikrobiologi pada Candida albicans. Jurnal Kedokteran Syiah Kuala, 16(1), 53-63. [In Bahasa Indonesia].

Nuryastuti, T., Setiawati, S., Ngatidjan, N., Mustofa, M.,
Jumina, J., Fitriastuti, D. and Mardjan, M.I.D. (2018). Antibiofilm activity of (1)-N-2methoxybenzyl-1,10-phenanthrolinium bromide against Candida albicans. Journal de Mycologie Médicale, 28(2), 367-373. https://doi.org/10.1016/ j.mycmed.2017.12.010

Olszewska, M.A., Gędas, A. and Simões, M. (2020). The Effects of Eugenol, Trans-Cinnamaldehyde, Citronellol, and Terpineol on Escherichia coli Biofilm Control as Assessed by Culture-Dependent and -Independent Methods. Molecules, 25(11), 2641. https://doi.org/10.3390/molecules25112641

Pierce, C.G., Uppuluri, P., Tummala, S. and LopezRibot, J.L. (2010). A 96 Well Microtiter Plate-based Method for Monitoring Formation and Antifungal Susceptibility Testing of Candida albicans Biofilms. Journal of Visualized Experiments, 44, 2287. https:// doi.org/10.3791/2287

Prakash, B., Veeregowda, B. and Krishnappa, G. (2003). Biofilms: A Survival Strategy of Bacteria. Current Science, 85(9), 1299-1307.

Pratiwi, S.U.T. and Hamzah, H. (2020). Inhibition and degradation activity of (Sapindus rarak seeds) ethanol extract against polymicrobial biofilm. Research Journal of Pharmacy and Technology, 13 (11), 5425-5430. https://doi.org/10.5958/0974360X.2020.00947.6

Pratiwi, S.U.T. and Hertiani, T. (2017). Efficacy of Massoia Oil in Combination With Some Indonesian Medicinal Plants Oils As Anti-Biofilm Agent Towards Candida albicans. International Journal of Pharmaceutical Sciences and Research, 8(5), 20132025. https://doi.org/10.13040/IJPSR.0975-8232.8 (5).2013-25

Pratiwi, S.U.T., Lagendijk, E.L., Hertiani, T., De Weert, S., Cornellius, A.M. and Van Den Hondel, J.J. (2015). Antimicrobial effects of indonesian medicinal plants extracts on planktonic and biofilm growth of Pseudomonas aeruginosa and Staphylococcus aureus. International Journal of Pharmacy and Pharmaceutical Sciences, 7(4), 183191. https://doi.org/10.4172/2376-0354.1000119

Ramage, G., Rajendran, R., Sherry, L. and Williams, C. (2012). Fungal Biofilm Resistance. International Journal of Microbiology, 2012, 528521. https:// doi.org/10.1155/2012/528521

Ramesh, N., Viswanathan, M.B., Saraswathy, A., Balakrishna, K., Brindha, P. and Lakshmanaperumalsamy, P. (2002). Phytochemical and antimicrobial studies of Begonia malabarica. Journal of Ethnopharmacology, 79(1), 129-132. https://doi.org/10.1016/S0378-8741(01)00352-X 
Rodríguez-Cerdeira, C., Gregorio, M.C., Molares-Vila, A., López-Barcenas, A., Fabbrocini, G., Bardhi, B., Sinani, A., Sánchez-Blanco, E., Arenas-Guzmán, R. and Hernandez-Castro, R. (2019). Biofilms and vulvovaginal candidiasis. Colloids and Surfaces B: Biointerfaces, 174, 110-125. https://doi.org/10.1016/ j.colsurfb.2018.11.011

Siregar, H.M., Wahyuni, S. and Ardaka, I.M. (2018). Karakterisasi Morfologi Daun Begonia Alam (Begoniaceae): Prospek Pengembangan Koleksi Tanaman Hias Daun di Kebun Raya Indonesia. Jurnal Biologi Indonesia, 14(2), 201-211. https:// doi.org/10.47349/jbi/14022018/201

Taufik, S., Yuniarni, U. and Hazar, S. (2015). Uji Aktivitas Ekstrak Pepaya (Carica papaya L.) Terhadap Escherichia coli dan Salmonella typhi. Prosiding Penelitian SPeSIA Unisba, 1(2), 654-661.

Undaharta, N.K.E., Sutomo, Ardaka, M. and Tirta, I.G. (2011). Autekologi Begonia Di Sebagian Kawasan Taman Nasional Manusela, Maluku. Jurnal Penelitian Hutan Dan Konservasi Alam, 9(1), 1-11. https://doi.org/10.20886/jphka.2012.9.1.001-011

Wiriadinata, H., Girmansyah, D., Hoover, S. and Hunter, J. (2002). Kekayaan Begonia Taman Nasional Gunung Halimun. Berita Biologi, 6(1), 91-97. [In Bahasa Indonesia]. 